\title{
Asthma and allergy practice and COVID-19: a review. Part I
}

According to the US Centers of Disease Control and Prevention (CDC), patients with asthma and allergies are at particular risk during the current COVID-19 pandemic. The aggressive SARS-CoV-2 virus mainly infects the lungs, most patients with asthma have an increased risk of infection and are likely to have a potentially more severe course of COVID-19.

The purpose of the analysis presented in this paper is to assess and forecast the prospects for establishing control over asthma and allergic diseases in a pandemic COVID-19.

According to the IPCRG, patients with asthma may not always be able to differentiate between asthma attacks and COVID-19 infection due to the similarity of respiratory symptoms. This leads to untimely care for SARS-CoV-2 and/or discontinuation of asthma treatment, which can have serious consequences. An important problem for practitioners is that patients with bronchoobstruction and allergy syndrome are often afraid of the risk of seeking medical attention during a COVID-19 pandemic and may confuse allergic symptoms with symptoms of coronavirus infection.

The U.S. Centers of Disease Control and Prevention has identified algorithms for providing non-COVID-19 care during a pandemic: to quickly detect and respond to an increase in COVID-19 cases among patients with asthma; provide assistance in the safest way; keep in mind that services may need to be gradually expanded.

\section{Key words}

Asthma, allergy, COVID-19, SARS-CoV-2, inflammation, glucocorticoids.

$\mathrm{P}$ eople with moderate to severe asthma may be at higher risk of getting very sick from COVID-19. COVID-19 can affect your nose, throat, lungs (respiratory tract); cause an asthma attack; and possibly lead to pneumonia and acute respiratory disease [1, 17].

How to prepare for COVID-19: make sure that you have at least a 30-day supply of your medicines; take everyday precautions like washing your hands, avoiding close contact, and staying at least 6 feet (about 2 arm lengths) from other people; wear masks in public settings and when around people who don't live in your household; when out in public, keep away from others and avoid crowds; wash your hands often with soap and water for at least

\footnotetext{
(C) Туберкульоз, легеневі хвороби, ВІЛ-інфекція, 2021

( С Л. ДюБаске, Л.Д. Тодоріко, Г.Д. Коваль, С.Д. Юр'єв,

I.0. Сем'янів, Н.В. Пашковська, О.С. Шевченко, 2021
}

20 seconds or use hand sanitizer that contains at least $60 \%$ alcohol; avoid cruise travel and nonessential air travel; during a COVID-19 spread (outbreak) in your community, stay home as much as possible to reduce your risk of being exposed; if someone in your home is sick, have them stay away from the rest of the household to reduce the risk of spreading the virus in your home [3].

Follow your asthma action plan [2, 4]:

1. Keep your asthma under control by following your asthma action plan.

2. Avoid your asthma triggers.

3. Continue current medications, including any inhalers with steroids in them («steroids» is another word for corticosteroids). Know how to use your inhaler.

4. Do not stop any medications or change your asthma treatment plan without talking to your healthcare provider. 


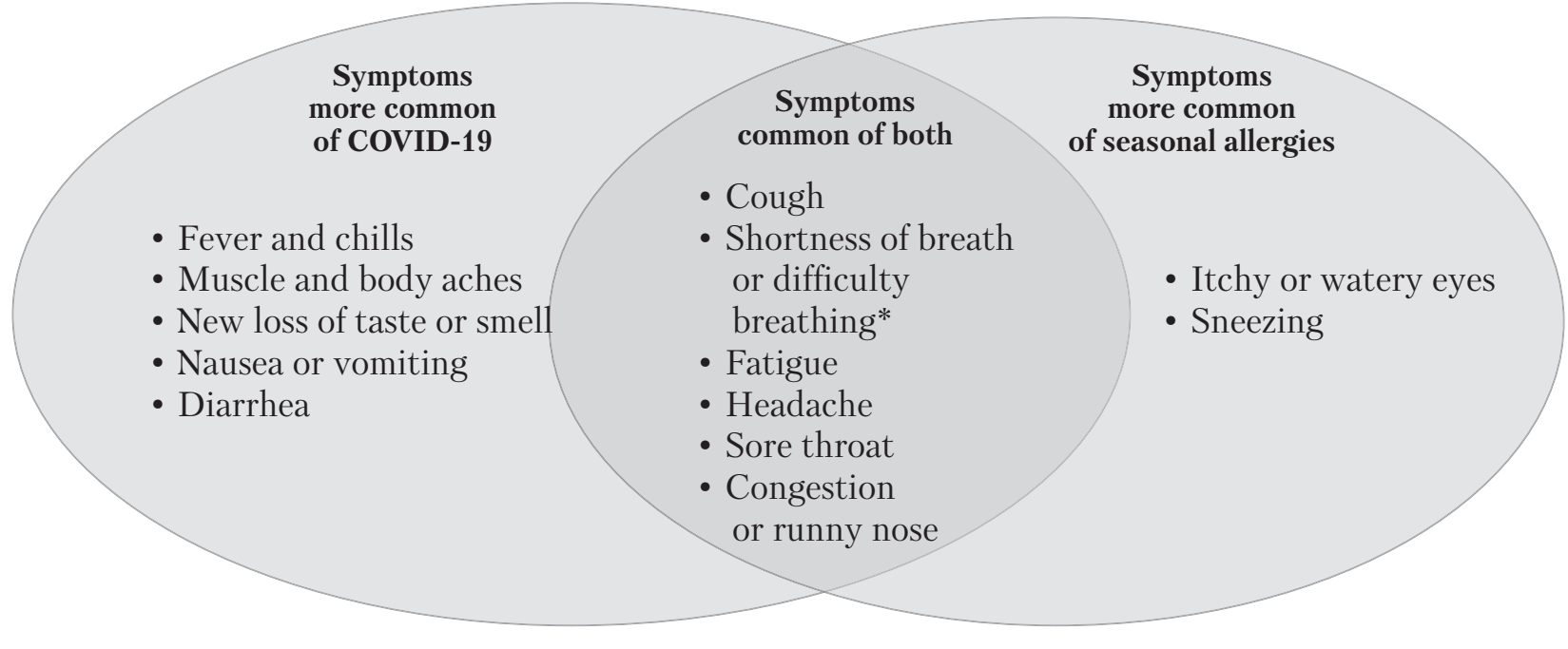

Fig. 1. Venn diagram of the overlap of COVID-19 symptoms with seasonal allergy symptoms [5]

5. Talk to your healthcare provider, insurer, and pharmacist about creating an emergency supply of prescription medications, such as asthma inhalers. Make sure that you have 30 days of nonprescription medications and supplies on hand in case you need to stay home for a long time.

6. Take steps to help yourself cope with stress and anxiety.

7. As more cases of COVID-19 are discovered and our communities take action to combat the spread of disease, it is natural for some people to feel concerned or stressed. Strong emotions can trigger an asthma attack.

Follow the recommendations below to reduce your chance of an asthma attack while disinfecting to prevent COVID-19 [10]. If you have asthma ask an adult without asthma to clean and disinfect surfaces and objects for you. Stay in another room when cleaners or disinfectants are being used and right after their use. Use only cleaning products you must use. Some surfaces and objects that are seldom touched may need to be cleaned only with soap and water. Make a list of the urgent care or health facilities near you that provide nebulizer/asthma treatments. Keep it close to your phone. If you have an asthma attack, move away from the trigger such as the disinfectant or the area that was disinfected. Follow your Asthma Action Plan. Call 911 for medical emergencies (Fig. 1) [5].

Higher airborne pollen concentrations correlated with increased SARS-CoV-2 infection rates, as evidenced from 31 countries.

Pollen exposure weakens the immunity against certain seasonal respiratory viruses by diminishing the antiviral interferon response [14, 20]. Here we investigate whether the same applies to the pandemic severe acute respiratory syndrome corona- virus 2 (SARS-CoV-2), which is sensitive to antiviral interferons, if infection waves coincide with high airborne pollen concentrations. Our original hypothesis was that more airborne pollen would lead to increases in infection rates. To examine this, we performed a cross-sectional and longitudinal data analysis on SARS-CoV-2 infection, airborne pollen, and meteorological factors. Our dataset is the most comprehensive, largest possible worldwide from 130 stations, across 31 countries and five continents. To explicitly investigate the effects of social contact, we additionally considered population density of each study area, as well as lockdown effects, in all possible combinations: without any lockdown, with mixed lockdown — no lockdown regime, and under complete lockdown. We found that airborne pollen, sometimes in synergy with humidity and temperature, explained, on average, $44 \%$ of the infection rate variability. Infection rates increased after higher pollen concentrations most frequently during the four previous days. Without lockdown, an increase of pollen abundance by 100 pollen $/ \mathrm{m}^{3}$ resulted in a $4 \%$ average increase of infection rates (Fig. 2) [7]. Lockdown halved infection rates under similar pollen concentrations [15].

As there can be no preventive measures against airborne pollen exposure, we suggest wide dissemination of pollen-virus coexposure dire effect information to encourage high-risk individuals to wear particle filter masks during high springtime pollen concentrations (Fig. 3) [7, 18].

Coexposure to airborne pollen enhances susceptibility to respiratory viral infections, regardless of the allergy status. We hypothesized this could be also true for SARS-CoV-2 infections. To investigate this, we tested for relationships between SARS-CoV-2 


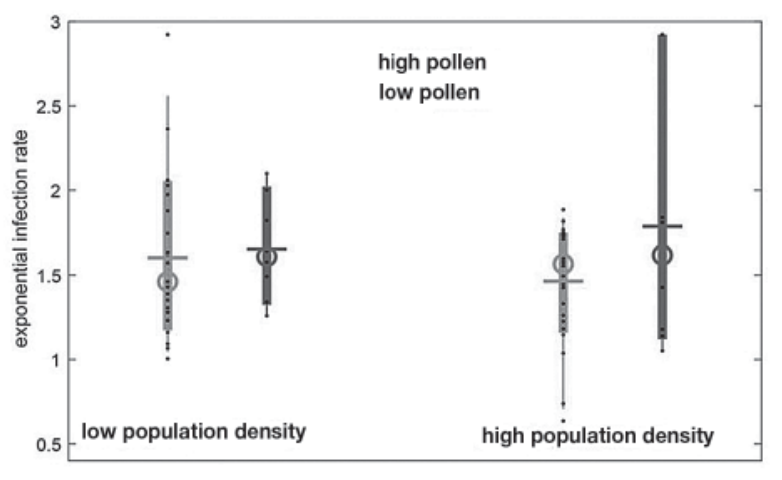

Fig. 2. SARS-CoV-2 infection rates are positively correlated with airborne pollen

Mean infection rate in the exponential phase for sites with low $\left(<1,000\right.$ inhabitants $\left./ \mathrm{km}^{2}\right)$ and high $\left(\geq 1,000\right.$ inhabitants $\left./ \mathrm{km}^{2}\right)$ population density and for low $\left(<250\right.$ pollen $\left./ \mathrm{m}^{3}\right)$ and high $\left(>250\right.$ pollen $\left./ \mathrm{m}^{3}\right)$ average pollen concentration during the 2 wk of near-constant infection rate. Only the regions and time intervals with no lockdown were selected.

infection rates and pollen concentrations, along with humidity, temperature, population density, and lockdown effects [4]. Our unique dataset derives from 130 sites in 31 countries and across five continents. We found that pollen, sometimes in synergy with humidity and temperature, explained, on average, $44 \%$ of the infection rate variability (Fig. 4) [11]. Lockdown halved infection rates under similar pollen concentrations. As we cannot completely avoid pollen exposure,

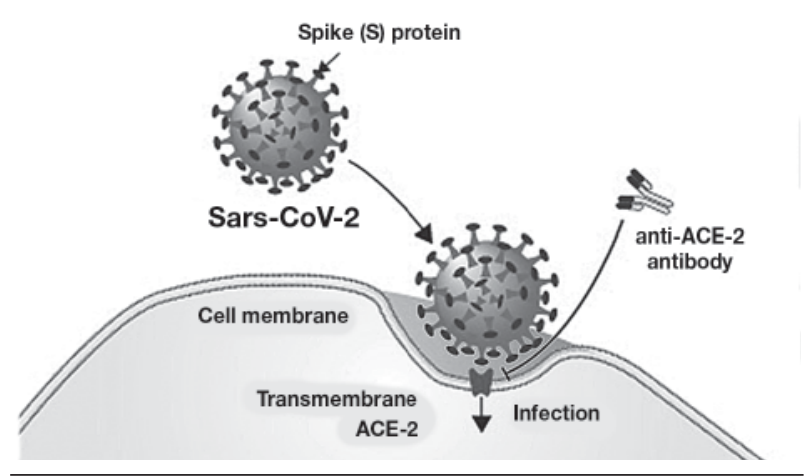

Fig. 4. ACE-2 is the host cell receptor responsible for mediating infection by SARS-CoV-2, the novel coronavirus responsible for coronavirus disease 2019 (COVID-19). Treatment with anti-ACE-2 antibodies disrupts the interaction between virus and receptor we suggest wide dissemination of pollen-virus coexposure information to encourage high-risk individuals to wear particle filter masks during high springtime pollen concentrations (Fig. 5) [6].

\section{The ACE-2 in COVID-19: Foe or Friend?}

The renin angiotensin system consists of renin which catalyzes the conversion of angiotensinogen to angiotensin 1 (Ang 1) (Fig. 6) [9, 12].
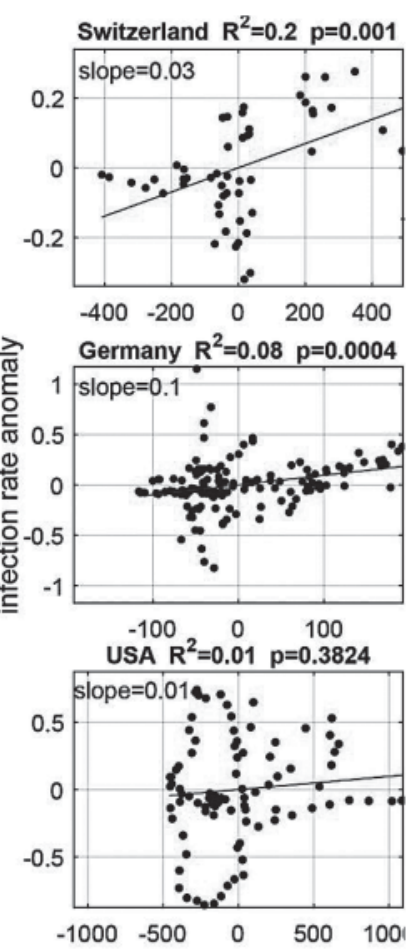
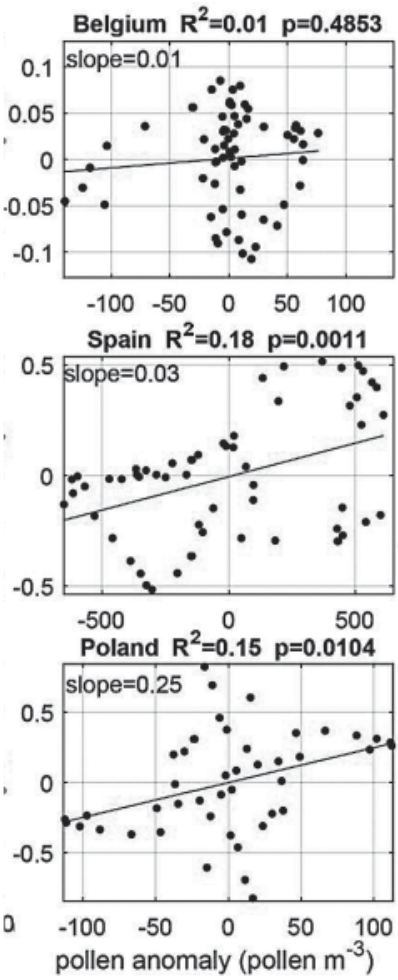

France $R^{2}=0.09 p=0.0005$
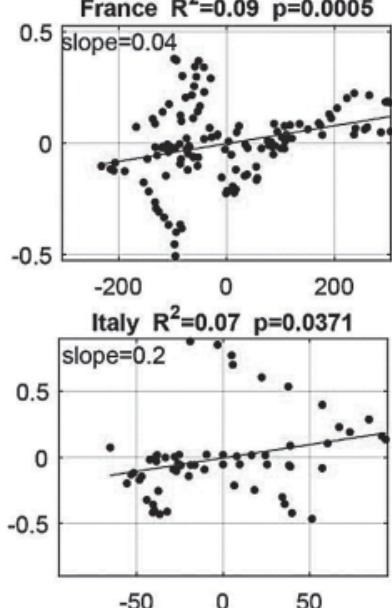

Fig. 3. SARS-CoV-2 infection rates are positively correlated with pollen concentrations in a longitudinal data analysis

Per site, anomalies of infection rates are plotted against anomalies in pollen concentrations (blue dots). The slope of the regression line represents the magnitude of the sensitivity of infection rates to pollen concentrations (infection rate per 100 pollen $/ \mathrm{m}^{3}$ ). Note the different scales in the panels, both in $\mathrm{x}$ axes and $\mathrm{y}$ axes. Only the regions from the geographically large or the bioclimatically diverse countries are analyzed here. 


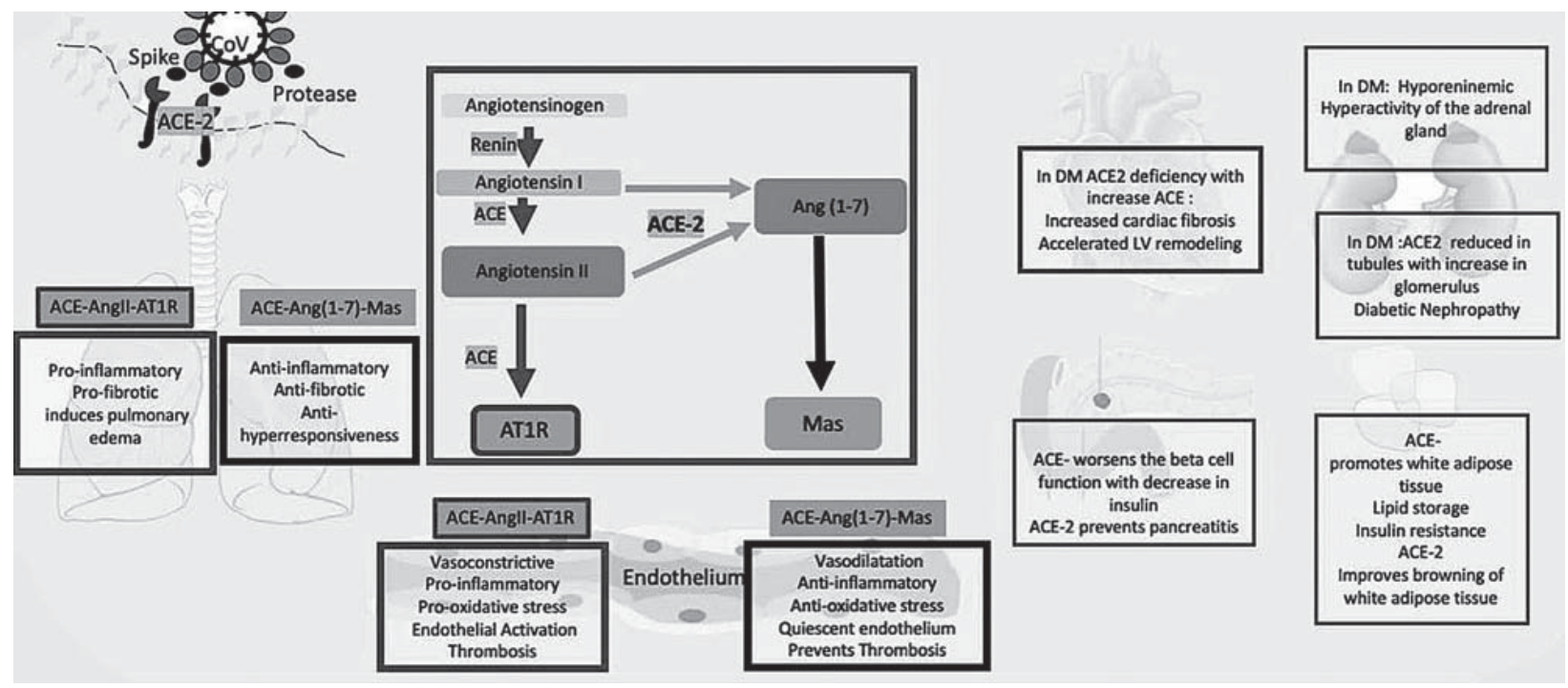

Fig. 5. Schematic Representation to show the renin angiotensin system in diabetes and the interaction of the SARS-CoV-2 with the ACE-2

The SARS-CoV-2 interacts with the ACE-2 through the spike proteins after priming by tissue serene proteases. It uses the ACE-2 protein to enter the alveo-lar cells in the lungs.

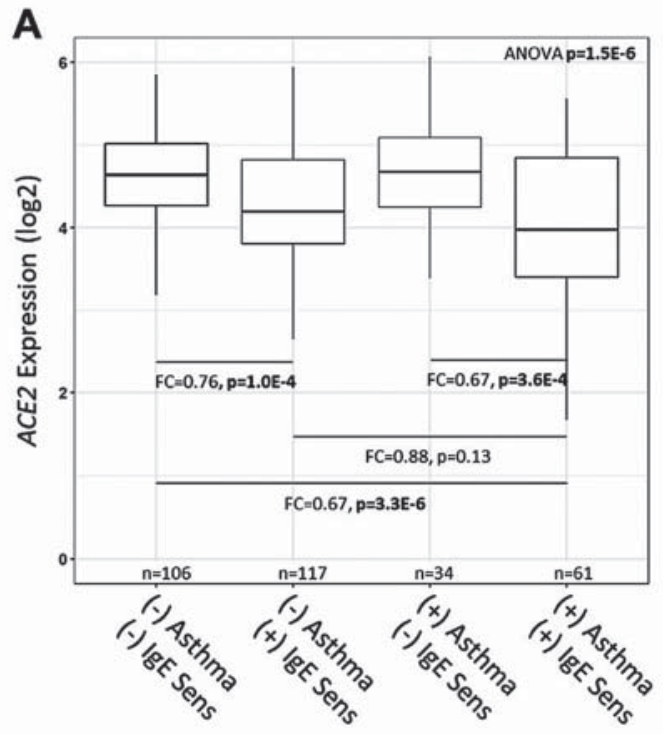

Asthma / Atopy Grouping
B

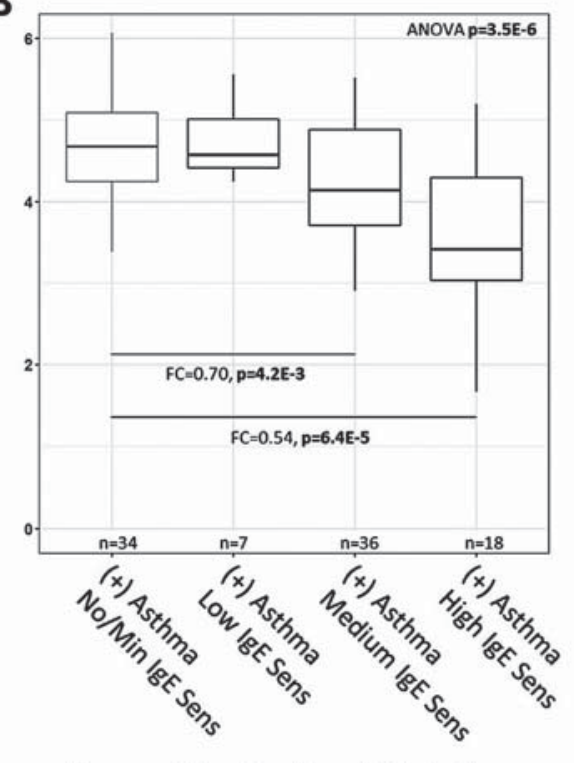

Degree of Sensitization within Asthma

Fig. 6. ACE2 expression is decreased in the nasal epithelium of children with allergic sensitization (Sens) and allergic asthma

1. The subsequent axis depends on the balance between the Angiotensin converting enzyme (ACE) and ACE-2.

2. ACE converts Ang 1 to Ang II and this acts in the angiotensin receptor (AT1R), whereas ACE-2 converts it to Ang-(1-7), which acts on the Mas receptor.

3. In the respiratory system activation of ACE leads to a proinflammatory, pro-fibrotic, pro-hyperresponsiveness response in the respiratory system, whereas ACE-2-Ang-(1-7)-Mas induces a protective mechanism of anti-inflammatory, anti- fibrotic and anti-hyperresponsiveness. A lower ACE-2 will put these individuals at higher risk of respiratory distress.

4. In hypertension, diabetes, and CVD, the ACE related pathway is activated with downregulation of the ACE-2 pathway. These results in the multiorgan complications seen in metabolic diseases with endothelial dysfunction promoting atherosclerosis, increased cardiac fibrosis and LV remodeling, diabetic nephropathy, hyperactivity of adrenal gland, and it decreases insulin release and increases insulin resistance. 


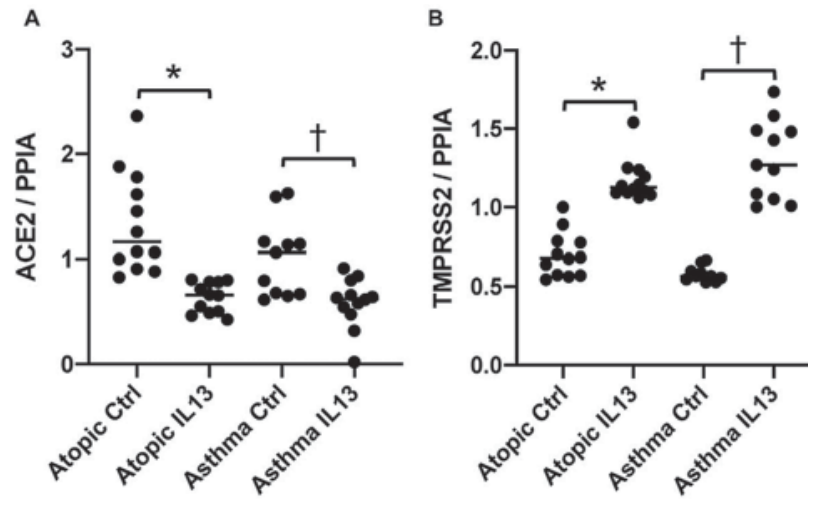

Fig. 7. IL-13 exposure reduces ACE2 and increases TMPRSS2 expression in airway epithelial cells

5. Infection with COVID-19 may exacerbate the ACE-2 deficiency in these patients in all organs and maybe responsible for the multiorgan failure.

\section{Association of respiratory allergy, asthma, and expression of the SARS-COV-2 receptor ACE2}

ACE2 expression levels in nasal brush samples from 11-year-old children in the URECA cohort according to asthma diagnosis by the age of 10 years, dichotomized as no $(-)$ or yes (1), and IgE sensitization trajectory at the age of 10 years, dichotomized as not/ minimally (no/Min) IgE-sensitized (-) or IgEsensitized (1), showing lower levels of ACE2 in children with atopy and atopic asthma. B, ACE2 expression in URECA children with asthma, subdivided according to the degree of IgE sensitization and demonstrating progressively lower levels of ACE2 according to the degree of IgE sensitization among children with asthma. Those children with both asthma and the highest IgE sensitization had the lowest levels of ACE2 expression [16, 22]. Expression levels are log2-transformed. Shown are median values (horizontal), interquartile ranges (boxes), and 1.53 interquartile range (whiskers). The printed FCs are for the non-log2-transformed expression values to aid in interpretation of the effect sizes (Fig. 7) [13].

IL-13 exposure reduces ACE2 and increases TMPRSS2 expression in airway epithelial cells from par- ticipants with asthma and atopy. A, IL-13 exposure significantly reduces ACE2 expression in nonasthma atopic (mean 51.27 [95 \% CI 5 1.05-1.54] vs mean 50.62 [95\% CI $0.54-0.71$ ]; P 5 0.0001) and asthmatic (mean 50.95 [95 \% CI 5 0.77-1.17] vs mean 50.47 [95 \% CI 5 0.27-0.82]; P 5 0.038) airway epithelial cells. B, IL-13 significantly increases TMPRSS2 expression in nonasthma atopic (mean 50.69 [95\% CI 5 0.62-0.77] vs mean 51.16 [95 \% CI 5 1.10-1.23]; P < 0.0001) and asthmatic (mean 50.58 [95 \% CI 0.55-0.61] vs mean 1.28 [95\% CI 1.15-1.44]; P < 0.0001) airway epithelial cells (Fig. 8) [13, 21].

The data from GSE19187 reveal no significant correlation between IL-4 and ACE2 (A) and between IL-5 and ACE2 (B). (C) IL-13 and ACE2 are significantly negatively correlated when all groups are combined. rs, Spearman rank correlation coefficient (Fig. 9) [13].

In the gene expression data set from adult participants in GSE4302, ACE2 expression is reduced in all asthma partici- pants compared with in healthy participants, with a trend toward significance (P 5 0.097) [8, 19]. B, Patients with T2-high asthma demonstrate lower airway epithelial ACE2 expression than healthy participants do. P 50.031 for the paired comparison. Box plots show medians with interquartile ranges (Fig. 10) [13].

Airway epithelial ACE2 is significantly negatively correlated with expression of IL-4, IL-5, and IL-13.

In data set GSE19187, participants with asthma and/or allergic rhinitis demonstrate increased nasal epithelial expression of TMPRSS2 compared with
A

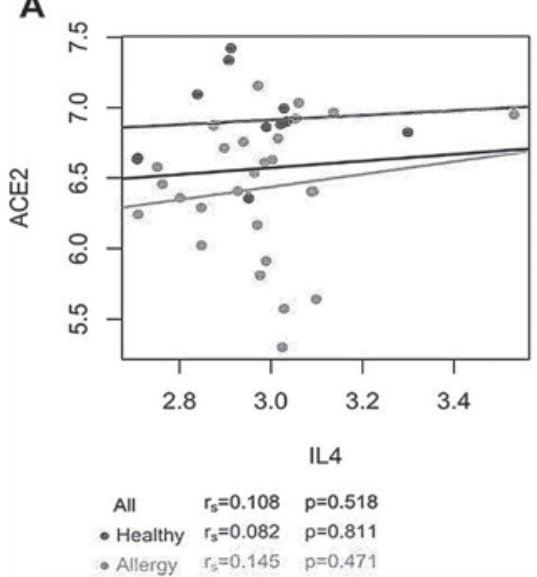

B

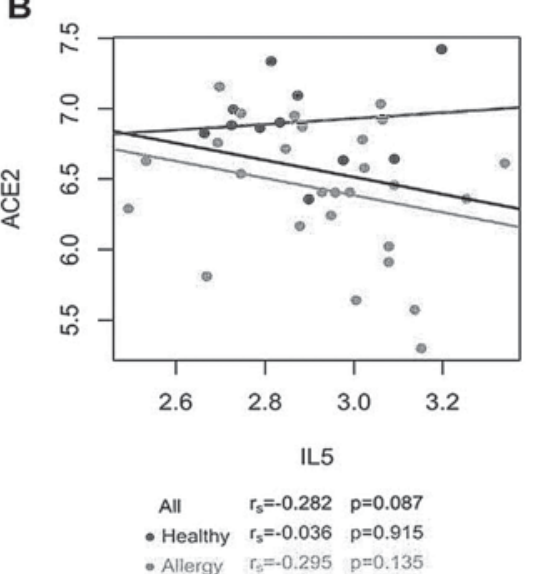

C

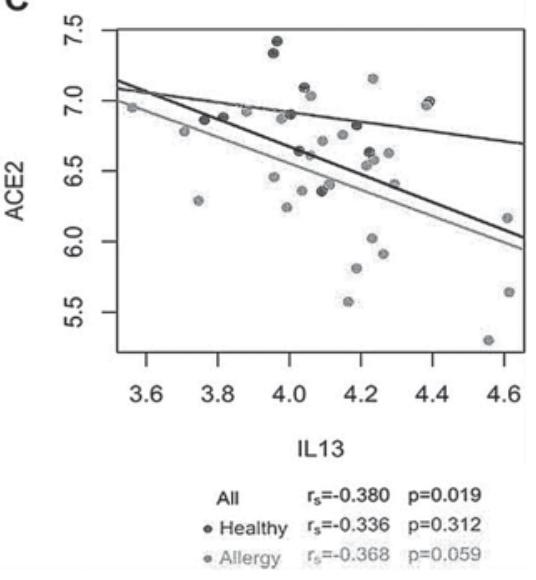

Fig. 8. ACE2 expression is significantly negatively correlated with IL-13 expression 
A

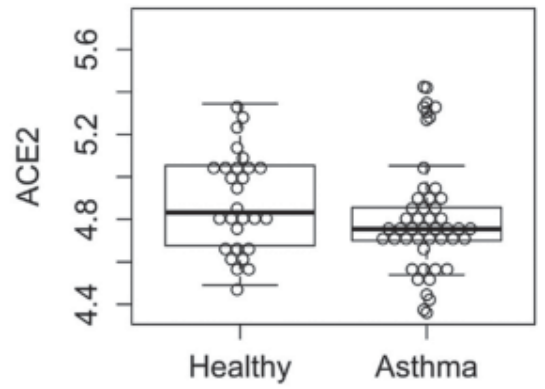

B

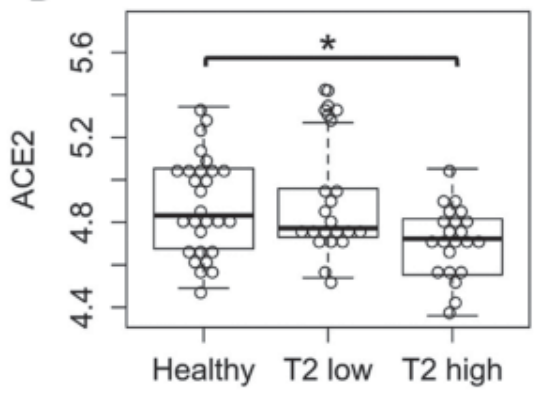

Fig. 9. ACE2 expression is decreased in airway epithelial cells in type 2 (T2)-high asthma

A

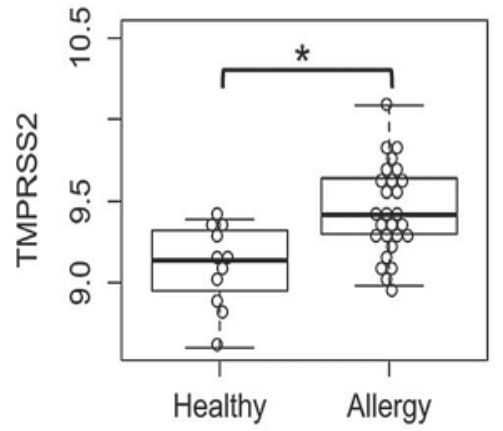

B

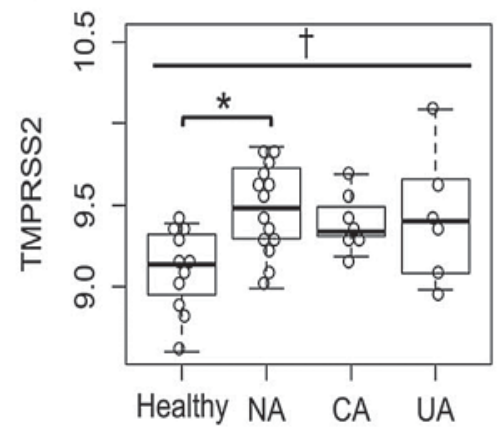

C

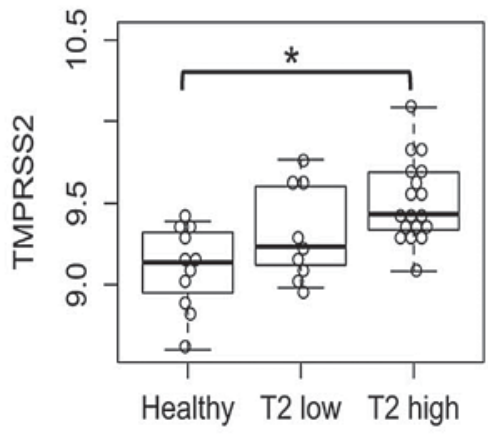

Fig. 10. TMPRSS2 gene expression is higher in nasal epithelial cells from type 2 (T2)-high participants with allergy

that demonstrated by healthy participants regardless of whether the allergy and asthma groups were combined (P 5 0.0022) (A) or evaluated as separate groups (P 50.018 for the paired comparison; P 5 0.034) (B). C, the T2-high participants demonstrate significantly higher expression of TMPRSS2, whereas the expression of TMPRSS2 by T2-low participants is similar to that demonstrated by healthy participants. P 5 .0012 for the paired comparison. Box plots show medians with interquartile ranges. CA, Rhinitis with controlled asthma; NA, rhinitis and no asthma; UA, rhinitis with uncontrolled asthma.

To fully cover this issue, we must divide the article into two parts. In the following we will continue to consider this issue.

\section{Conclusions}

In the near future, as a result of prognostic linear analysis, an increase in the incidence of $\mathrm{BA}$ is expected in the world, due to the constant presence of risk factors that provoke, including the SARS$\mathrm{CoV}$-2 virus, the development of the disease, as well as due to the rapid growth of allergic population.

GINA emphasizes the poor adherence to the algorithm of the proposed strategy of anti-inflammatory therapy and not esthisas a modifying risk factor for exacerbations in COVID-19. Significant for the control of inflammation in asthma actions of corticosteroid sare mediated at the molecular level through genomic dextra genomic mechanisms.

Конфлікту інтересів немає. Учать авторів: концепція і дизайн дослідження - Lawrence DuBuske; збір матеріалу - Lawrence DuBuske; обробка матеріалу - Lawrence DuBuske, Л.Д. Тодоріко, С.Д. Юр'єв; написання тексту та статистичне опрацювання даних - Lawrence DuBuske, Л.Д. Тодоріко, Г.Д. Коваль, Н.В. Пашковська, О.С. Шевченко; редагування тексту - Л.Д. Тодоріко, Г.Д. Коваль, І.О. Сем'янів, О.С. Шевченко. 


\section{References}

1. Адаптована клінічна настанова, заснована на доказах, «Бронхіальна астма».- К.: Національна академія медичних наук України, 2019.

2. Гузій О.В. Бронхообструктивні захворювання: нові клінічні настанови та позиція МОЗ України // Укр. мед. часопис.IX/X 2019.- № 5 (2) (133). https://www.umj.com.ua/ article/163544/bronhoobstruktivni-zahvoryuvannya-noviklinichni-nastanovi-ta-pozitsiya-moz-ukrayini.

3. Тодоріко Л.Д., Петренко В.І., Островський М.М. та ін. Бронхіальна астма - нова парадигма у клінічних рекомендаціях GINA. Частина 1 // Туберкульоз, легеневі хвороби ВІЛ- інфекція.-2020.-Vol.1 (40).- P.94-102. doi: 10.30978 TB2020-1-69.

4. Centers for Disease Control and Prevention (CDC). Updated June 30, 2020. Accessed August 14, 2020. https://www.cdc.gov/ coronavirus/2019-ncov/hcp/framework-non-COVID-care.html.

5. Content source: National Center for Immunization and Respiratory Diseases (NCIRD), Division of Viral Diseases. Last Updated Sept. 10, 2020.

6. Dalan R., Bornstein S.R., El-Armouche A. et al. The ACE-2 in COVID-19: Foe or Friend? // Horm. Metab. Res.- 2020.Vol. 52 (5).- P. 257-263. doi: 10.1055/a-1155-0501.

7. Damialis A., Gilles S., Sofiev M. et al. Higher airborne pollen concentrations correlated with increased SARS-CoV-2 infection rates, as evidenced from 31 countries across the globe // PNAS.- 2021.- Vol. 118 (12).- P. e2019034118. doi: 10.1073/ pnas.2019034118

8. Global Initiative for Asthma. Difficult-to-treat and severe asthma in adolescent and adult patients - Diagnosis and Management. A GINA Pocket Guide for Health Professionals V2.0. Fontana, WI, USA: GINA, 2019. https://ginasthma.org/ wp-content/uploads/2019/06/GINA-2019-main-report-June2019-wms.pdf.

9. Global Initiative for Asthma. Global Strategy for Asthma Management and Prevention, 2019. www.ginasthma.org.

10. Harvard Health Publishing [Internet]. Harvard Medical School, Boston; 2020. Available fr om: https://www.health.harvard edu/a_to_z/asthma-a-to-z.

11. ACE-2: The Receptor for SARS-CoV-2. https://www.rndsystems $\mathrm{com} /$ resources/articles/ace-2-sars-receptor-identified.

12. Jackson D.J., Busse W.W., Bacharier L.B. et al. Association of respiratory allergy, asthma, and expression of the SARS-CoV-2 receptor ACE //J. Aller. Clin. Immunol.-2020. - Vol. 146(1).P. 203-206. doi: 10.1016/j.jaci.2020.04.009
13. Kimura H., Francisco D., Conway M. et al. Type 2 inflammation modulates ACE2 and TMPRSS2 in airway epithelial cells // J. Allergy Clin. Immunol.- 2020.- Vol. 146 (1).- P. 80-88. doi: 10.1016/j.jaci.2020.05.004.

14. Klimek L. et al. ARIA, Allergic Rhinitis and its Impact on Asthma; EAACI, European Academy of Allergy and Clinical Immunology; IgG, immunoglobulin G; IgM, immunoglobulin M; RT-PCR, reverse transcriptase polymerase chain reaction; SCIT, subcutaneous immunotherapy; SLIT, sublingual immunotherapy // Allergy.- 2020.- Vol. 75 (7).- P. 15461554

15. Ostrovskyy M.M., Varunkiv O.I., Todoriko L.D. Nitric oxide metabolism in patients with community-acquired pneumonia associated with coronary heart disease and the possibility of its medicamentous management // Wiadomości Lekarskie.2020.- Vol. UME LXXIII.- P 1707-1711. doi: 10.36740/ WLek202008122

16. Reddel H.K., FitzGerald J.M., Bateman E.D. et al. GINA 2019: a fundamental change in asthma management: Treatment of asthma with short-acting bronchodilators alone is no longer recommended for adults and adolescents // Eur. Respir. J.- 2019.- Vol. 53 (6).- P. 1901046. doi: 10.1183/13993003.01046- 2019.

17. SARS-CoV-2, severe acute respiratory syndrome coronavirus 2. American Academy of Allergy, Asthma \& Immunology (AAAAI). Published March 25, 2020. Accessed August 14, 2020. https:// education.aaaai.org/immunotherapy covid-19.

18. Shaker M.S. et al. COVID-19: Pandemic Contingency Planning for the Allergy and Immunology Clinic // J. Allergy Clin. Immunol. Practice.- 2020.- Vol. 8 (5).- P. 1477-1488. doi: 10.1016/j.jaip.2020.03.012

19. Suissa S. Inhaled corticosteroids preventing pneumonia mortality: paradox or selection bias? // Eur. Respir J.- 2019.Vol. 53 (2).- P. 1802112. doi: 10.1183/13993003.02112-2018.

20. Shvets O.M., Shevchenko O.S., Todoriko L.D. Carbohydrate and lipid metabolic profiles of tuberculosis patients with bilateral pulmonary lesions and mycobacteria excretion // Wiad. Lek2020.-Vol.73(7).-P.1373-1376.doi:10.36740/wlek202007113.

21. Svedsater H., Jones R., Bosanquet N. et al. Patient-reported outcomes with initiation of fluticasone furoate/vilanterol versus continuing usual care in the Asthma Salford Lung Study // Respir. Med.- 2018.- Vol. 141.- P. 198-206. doi: 10.1016/j. rmed.2018.06.003.

22. Yaghoubi M., Adibi A., Safari A. et al. The Projected Economic and Health Burden of Uncontrolled Asthma in the United States // Am. J. Respir. Crit Care Med._-2019.- Vol. 200 (9).P. 1102-1112. doi: 10.1164/rccm.201901-0016OC.

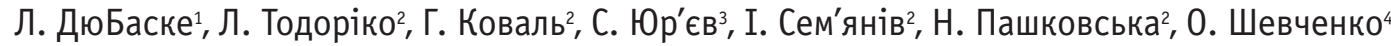 \\ ${ }^{1}$ Медична школа університету Джорджа Вашингтона, Вашингтон, США \\ 2Буковинський державний медичний університет, Чернівці \\ ${ }^{3}$ Національний медичний університет імені 0.0. Богомольця, Київ \\ ${ }^{4}$ Харківський національний медичний університет}

\section{Практичні питання астми й алергї̈ та COVID-19 Огляд літератури. Частина I}

Згідно з даними Центру контролю і профілактики захворювання США (CDC) під час нинішньої пандемії COVID-19 пацієнти з астмою та алергією належать до групи особливого ризику. А оскільки агресивний вірус SARS-CoV-2 переважно уражає легені, у більшості пацієнтів з бронхіальною астмою (БА) є наявним підвищений ризик зараження та, ймовірно, потенційно більш тяжчий перебіг COVID-19.

Метою аналізу, наведеного у цій роботі, є оцінка та прогноз перспектив установлення контролю над БА та алергійними захворюваннями в умовах пандеміі COVID-19.

За даними IPCRG, пацієнти з БА не завжди можуть диференціювати симптоми нападу астми та інфікування COVID-19, що пов'язано зі спорідненістю респіраторних симптомів. Це призводить до несвоєчасного надання допомоги при SARS-CoV-2 та/або припинення лікування БА, що може мати 
серйозні наслідки. Вагомою проблемою для практичної медицини є те, що часто пацієнти із синдромом бронхообструкції та алергії бояться ризику, пов’язаного зі зверненням по медичну допомогу під час пандемії COVID-19 та можуть плутати алергійні симптоми із симптомами коронавірусної інфекції.

Американським центром контролю та профілактики захворювань виділено алгоритми надання медичної допомоги, не пов'язаної з COVID-19, під час пандемії: швидко виявляти та реагувати на збільшення кількості випадків COVID-19 серед пацієнтів з астмою; надавати допомогу в найбільш безпечний спосіб; враховувати, що послуги, можливо, доведеться поступово розширювати.

Ключові слова: астма, алергія, COVID-19, SARS-CoV-2, запалення, глюкокортикоїди.

Л. ДюБаске ${ }^{1}$, Л. Тодорико ${ }^{2}$, Г. Коваль², С. Юрьев ${ }^{3}$, И. Семьянив ${ }^{2}$, Н. Пашковская ${ }^{2}$, О. Шевченко

${ }_{1}^{1}$ Медицинская школа университета Джорджа Вашингтона, Вашингтон, США

${ }^{2}$ Буковинский государственный медицинский университет, Черновцы

${ }^{3}$ Национальный медицинский университет имени А.А. Богомольца, Киев

${ }^{4}$ Харьковский национальный медицинский университет

\section{Практические вопросы астмы и аллергии и COVID-19 Обзор литературы. Часть I}

Согласно данным Центра контроля и профилактики заболевания США (CDC) во время нынешней пандемии COVID-19 пациенты с астмой и аллергией относятся к группе особого риска. А поскольку агрессивный вирус SARS-CoV-2 преимущественно поражает легкие, у большинства пациентов с бронхиальной астмой (БА) наблюдается повышенный риск заражения и, вероятно, потенциально более тяжелое течение COVID-19.

Целью анализа, приведенного в данной работе, является оценка и прогноз перспектив установления контроля над БА и аллергическими заболеваниями в условиях пандемии COVID-19.

По данным IPCRG, пациенты с БА не всегда могут дифференцировать симптомы приступа астмы и инфицирования COVID-19, что связано с родством респираторных симптомов. Это приводит к несвоевременному оказанию помощи при SARS-CoV-2 и/или прекращению лечения БА, что может иметь серьезные последствия. Весомой проблемой для практической медицины является то, что часто пациенты с синдромом бронхообструкции и аллергии боятся риска, связанного с обращением за медицинской помощью во время пандемии COVID-19 и могут путать аллергические симптомы с симптомами коронавирусной инфекции.

Американским центром контроля и профилактики заболеваний выделены алгоритмы оказания медицинской помощи, не связанной с COVID-19 во время пандемии: быстро выявлять и реагировать на увеличение количества случаев COVID-19 среди пациентов с астмой; оказывать помощь в наиболее безопасный способ; учитывать, что услуги, возможно, придется постепенно расширять.

Ключевые слова: астма, аллергия, COVID-19, SARS-CoV-2, воспаление, глюкокортикоиды.

\section{Контактна інформація:}

Тодоріко Лілія Дмитрівна, д. мед. н., проф., зав. кафедри фтизіатрії та пульмонології 58002, м. Чернівці, Театральна площа, 2

E-mail: pulmonology@bsmu.edu.ua

Стаття надійшла до редакції 20 травня 2021 р.

\section{для цитувАння}

- DuBuske L., Todoriko L., Koval H., Yuriev S., Semianiv I., Pashkovska N., Shevchenko O. Asthma and allergy practice and COVID-19: a review. Part I // Туберкульоз, легеневі хвороби, ВІЛ-інфекція. - 2021. - № 2. - С. 44-51. doi: 10.30978/ТВ-2021-2-44.

- DuBuske L, Todoriko L, Koval H, Yuriev S, Semianiv I, Pashkovska N, Shevchenko O. Asthma and allergy practice and COVID-19: a review. Part I. Tuberculosis, Lung Diseases, HIV Infection. 2021;2:44-51. doi:10.30978/TB-2021-2-44. 